DOI: $10.2478 / \mathrm{v} 10025-009-0006-9$

\title{
Quality aspects of the surface water used for irrigation in the Neretva Delta (Croatia)
}

\author{
Davor ROMIĆ, Monika ZOVKO, Marija ROMIĆ, \\ Gabrijel ONDRA ̌́EK, Zoran SALOPEK
}

University of Zagreb Faculty of Agriculture, Svetošimunska 25, 10000 Zagreb, Croatia; phone: +385 1 2393788, fax: +385 1 2394099; e-mail: dromic@agr.hr

\begin{abstract}
The research was set up in the Neretva River valley in the Southern part of Croatian Karst area, where implementation of modern hydrotechnical practices within the river catchment's area led to intrusion of seawater to groundwater resulting in soil salinization in the delta. The region has great agro-ecological potential for intensive production of vegetables and Mediterranean fruits. Since the combination of the effects of saline groundwater and the use of this water for irrigation may have disastrous effects on the productivity of agricultural soils water, a project was started in order to set up a permanent monitoring network. The aim of this study was to determine the salt dynamics in the surface water on five locations which are considered as potential sources of the irrigation water (Modric canal, Neretva River near Opuzen, Crepina, Jasenska and Vidrice pumping station) during a 4-year period (1999-2002). The surface water samples had been collected on monthly basis and analyzed for all parameters required in the irrigation water quality classification. The results show considerable spatial and temporal variability of determined parameters. Thus, in the Neretva River near Opuzen, total salt concentrations in water ranged from 0.4 to $7.7 \mathrm{dS} \cdot \mathrm{m}^{-1}$, and in Modric from 1.65 up to17.2 $\mathrm{dS} \cdot \mathrm{m}^{-1}$. Dominant cations and anions on all observed locations were $\mathrm{Na}^{+}$and $\mathrm{Cl}^{-}$. Constantly high concentration of $\mathrm{Na}^{+}$in sampled surface waters is of a special concern. Utilization of the water of such quality may cause problems related to the use of alkaline waters for irrigation, which can further cause permanent loss of fertile soil.
\end{abstract}

Key words: sea water intrusion, water regime, irrigation, salinized water, soil salinization

\section{INTRODUCTION}

The Neretva River Valley characterizes specific landscape in Southern Croatia, cut into the Karst limestone-dolomite environment, with great potentials for the production of vegetables and Mediterranean fruits. Typical Mediterranean climatic conditions and abounds in water ensured development of agriculture as an important branch of economy where more than 30 thousand people directly or indirectly make a living from agricultural production. Nevertheless agricultural production 
becoming more endangered because of periodical or temporal salinization of the surface and underground water downstream of the town Metkovic (ROMIĆ, 1999). Two natural ways of salinization were determined in the Neretva valley: through the river mouth and by the costal aquifer through underground. Whereas agricultural production in this area is unfeasible without irrigation, farmers are forced to use water of low quality, usually highly saline due to sea water intrusion. Use of saline water for irrigation may have disastrous effects on the productivity of agricultural soils.

The natural values and the diversity of habitats in this area depend in the first place upon the water regime affected by the Neretva River. Owing to many underground karst streams of the basin, in the part adjacent with the surrounding limestone terrain, there are many springs carrying large amounts of water, especially in winter. The ground water coming from this adjacent area supplies numerous streams, lakes and cavities. An important factor affecting the delta is the sea, and the bodies of brackish water present special habitats which contribute additionally to the biological diversity of this whole area.

Intensive agriculture is often, with more or less justification, called as one of the potentially important sources of pollution of the environment, especially of aquatic eco-systems, which is for the Neretva Valley a crucial question of the system sustainability. Agricultural practice has been therefore faced with an important task, that of promoting and improving techniques and technologies that will not be a threat to the natural functions of soil, and will protect surface and groundwater from the contamination from such sources. Monitoring the quality of surface water enables the prediction of the salinization processes and devise adequate crop growing scheme to protect water and soil. Therefore, the surface water monitoring program has been established in 1997 on 22 locations which are considered as potential sources of irrigation water in the Neretva River Valley.

The main objectives of this study were to: (i) analyse the variations of the salt concentrations in water on the locations used as a sources of the irrigation water; (ii) determine the relations between the salt concentrations in the Neretva River near Opuzen and the data on water levels and precipitation; (iii) assess the influence of the climatic parameters, first of all rainfall, on the salt concentrations in water on the monitoring locations.

\section{MATERIALS AND METHODS}

\section{STUDY SITE}

The research was carried out in the Neretva River Valley (Fig. 1) in the Mediterranean part of Croatia $\left(43^{\circ} 00^{\prime} \mathrm{N}, 17^{\circ} 30^{\prime} \mathrm{E}\right)$. The Neretva River runs 225 kilometers and only $22 \mathrm{~km}$ through Croatia. The upper river flows swiftly through 


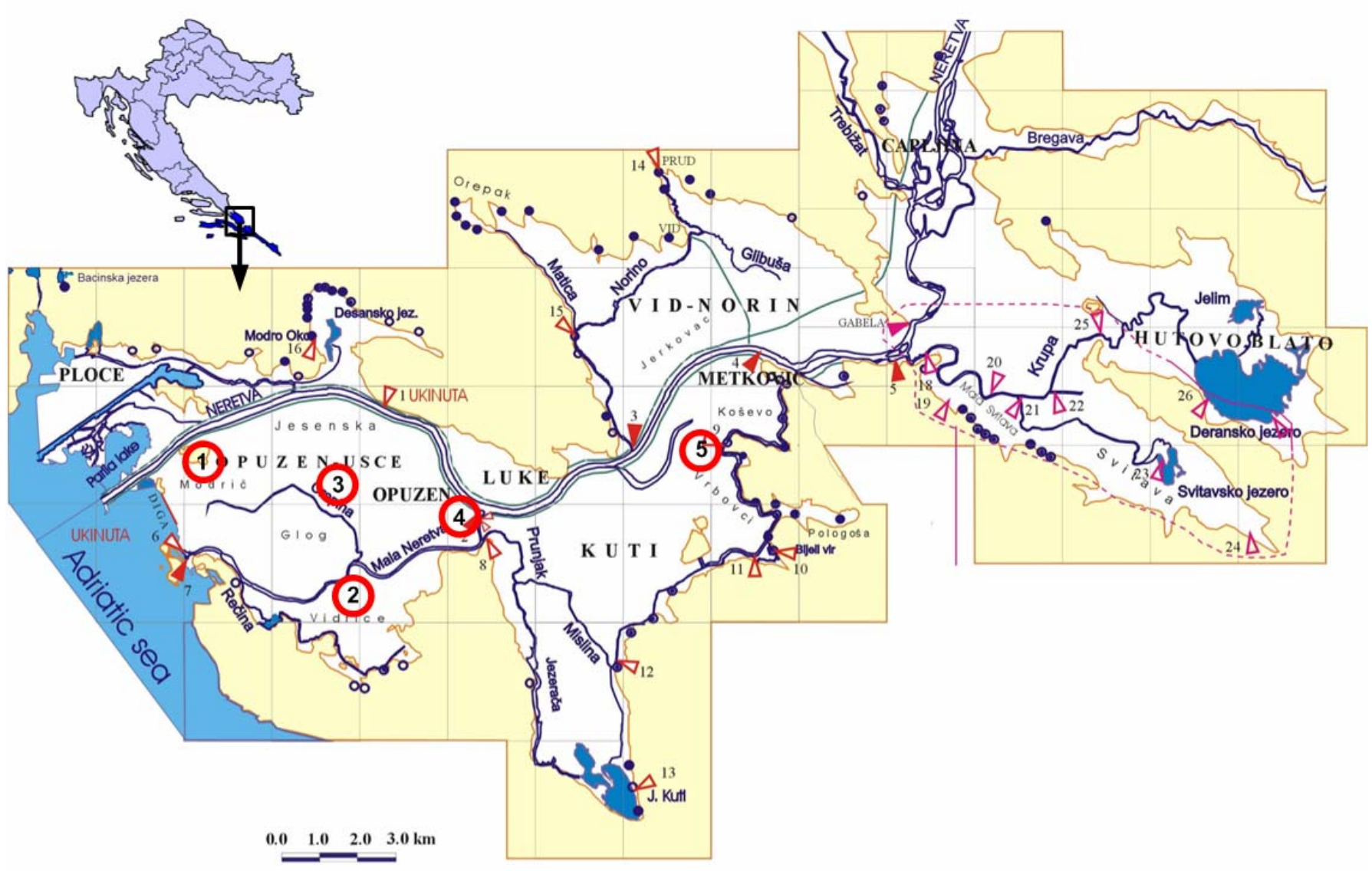

Fig. 1. Map of the Neretva Delta Valley - water quality monitoring stations: 1 - Modric; 2 - Vidrice; 3 - Crepina; 4 - Neretva near Opuzen; 5 - Jasenska 
a mountainous landscape, while the last $30 \mathrm{~km}$ spreads into an alluvial delta before emptying into the Adriatic Sea. The Neretva's lower course and delta were shaped by high waters that periodically washed down from the mountains, bringing dissolved organic substrate, the sedimentation of which created fertile soil. In the lower valley in Croatia, the Neretva River splinters into multiple courses, creating a delta covering approximately 12,000 hectares. The delta in Croatia has been reduced by extensive land reclamation projects, and now flows in just three branches, a drop from the previous 12. The marshes, lagoons and lakes that once dotted this plain have disappeared and only fragments of the old Mediterranean wetlands have survived. Nowadays, the main river-bed in the downstream part is under the strong influence of the Adriatic Sea and that's why physical, chemical and ecological processes are similar to those in estuaries.

The area is semi-arid with a Mediterranean climate of hot, dry summers and wet winters. Most rainfall occurs in the period from October to April, with an annual average (1980-2000) of $1230 \mathrm{~mm}$. The mean annual air temperature is $15.7^{\circ} \mathrm{C}$, with the highest $\left(25.2^{\circ} \mathrm{C}\right)$ in July. Annual Penman-Montheith reference evapotranspiration amounts to $1196 \mathrm{~mm}$, the highest of $191 \mathrm{~mm}$ occurring in July. Climatic conditions are favorable for the field crop production throughout the year. The most of about 6000 ha of land are used for the field vegetable production, along with irrigation as an obligatory growing measure.

On five monitoring locations at Modric canal, the Neretva River near Opuzen, Crepina, Jasenska and Vidrice pumping station, quality of water available for irrigation was monitored during a 4-year period (1999-2002). These five locations were selected according their potential as sources of irrigation water. There are a three types of monitoring stations: natural water courses, pumping stations and drainage channels. Locations Neretva near Opuzen and Crepina, are considered as a natural river courses. Vidrice is pumping station which is programmed to maintain the level of underground water. Modric is the main drainage channel which collects surface and underground water and Jasenska is channel which transports collected water into the pumping station.

Climatic data for the period 1999-2001 were used for assessing the effect of precipitation on the variation of the surface water salinity on the selected monitoring stations. Water level was measured in Neretva River near Opuzen in 1-hour periods providing very dense time series, and average daily water level was used for the same date when the water sample was taken.

\section{MEASUREMENTS AND DATA PROCESSING}

To evaluate the suitability of irrigation water, parameters required for the classification were determined and the potential salinity problem caused by excessive salts in the irrigation water is evaluated by the FAO guidelines (AYERS and WESTCOT, 1992). 
During the 4-year period, 202 surface water samples were analysed. Standard protocols for sampling, sample stabilization and analysis were adopted for all water quality variables: $\mathrm{pH}$, electrical conductivity $\left(E C \mathrm{dS} \cdot \mathrm{m}^{-1}\right)$ and ionic composition (Standard..., 1995). For the purpose of this paper only the concentrations of chloride and sodium are presented because to main cause of the water salinity is sea water intrusion.

Basic statistical analysis was performed. The level of relationship of the temporal series in bivariate analysis was determined by correlation: (i) between the average salt concentrations in water sampled on the monitoring locations and average monthly rainfall measured on the climatological station in Opuzen, and (ii) between average salt concentrations in water on the monitoring station Opuzen and water level of the Neretva River near Opuzen. The data obtained were statistically processed using the computer program Statistica Version 7.1 (Statistica, 2006).

\section{RESULTS}

\section{DYNAMICS OF THE SURFACE WATER SALINITY}

When the problem of salinization appears, the most common parameters used for the evaluation of the water suitability for irrigation are electrical conductivity $\left(E C_{i w}\right)$, sodium adsorption ratio (SAR) and the concentration of potentially toxic ions - sodium, chloride, boron and trace metals (AYERS and WESCOT, 1992). Basic statistical data on $\mathrm{pH}, E C_{i w}$, sodium and chloride concentration in the monitoring locations are presented in Table 1.

The highest quality of water was determined on the Neretva Opuzen location, where the average value of the electrical conductivity was lower than $2 \mathrm{dS} \cdot \mathrm{m}^{-1}$ and this water was classified as slightly saline according the FAO criteria. On the other monitoring locations, water quality was assessed as moderately saline. The highest $E C_{i w}$ values exceeded $10 \mathrm{dS} \cdot \mathrm{m}^{-1}$. Waters of such quality are considered as highly saline. The lowest average $E C_{i w}$ values were determined on the Vidrice monitoring station $\left(E C_{i w}=7.23 \mathrm{dS} \cdot \mathrm{m}^{-1}\right)$. The most equable $\mathrm{EC}_{\mathrm{iw}}$ values were marked out in the water of the channel Modric. Nevertheless, the values of the analyzed parameters were rather high, reaching the critical level of $E C_{i w}>5 \mathrm{dS} \cdot \mathrm{m}^{-1}$ in summer months. Only some of the salt tolerant crops can be irrigated with the water of the $E C_{i w}>5$ $\mathrm{dS} \cdot \mathrm{m}^{-1}$ (MAAS, 1986).

Electrical conductivity is only one of the parameters usually used for assessing water quality for irrigation. In addition, the water ionic composition should be determined. In analyzed water samples from all monitoring locations, the prevailing ions were $\mathrm{Na}^{+}$and $\mathrm{Cl}^{-}$. Maximum sodium and chloride concentrations correspond to the high conductivity values. The highest concentrations of sodium $\left(2750 \mathrm{mg} \cdot \mathrm{l}^{-1}\right)$ and chloride $\left(5885 \mathrm{mg} \cdot \mathrm{l}^{-1}\right)$ ware measured in water on the Modric monitoring station. 
Table 1. Basic statistical data on $E C_{w}, \mathrm{Na}^{+}$and $\mathrm{Cl}^{-}$concentrations in water at the monitoring sites (1999-2002)

\begin{tabular}{|c|c|c|c|c|c|}
\hline Location & $\begin{array}{c}\text { Statistical } \\
\text { parameters }\end{array}$ & $\mathrm{pH}$ & $\begin{array}{c}E C_{i w} \\
\mathrm{dS} \cdot \mathrm{m}^{-1}\end{array}$ & $\begin{array}{c}\mathrm{Na}^{+} \\
\mathrm{mg} \cdot 1^{-1}\end{array}$ & $\begin{array}{c}\mathrm{Cl}^{-} \\
\mathrm{mg} \cdot 1^{-1}\end{array}$ \\
\hline \multirow[t]{4}{*}{ Vidrice } & mean & 7.74 & 7.23 & 1125 & 2440 \\
\hline & $\min$ & 6.80 & 1.30 & 140 & 308 \\
\hline & $\max$ & 8.40 & 12.70 & 2087 & 4892 \\
\hline & $S D$ & 0.37 & 2.34 & 441 & 942 \\
\hline \multirow[t]{4}{*}{ Modric } & mean & 7.72 & 5.53 & 763 & 1732 \\
\hline & $\min$ & 7.00 & 1.65 & 170 & 355 \\
\hline & $\max$ & 8.60 & 17.20 & 2750 & 5885 \\
\hline & $S D$ & 0.34 & 3.43 & 560 & 1225 \\
\hline \multirow[t]{4}{*}{ Jasenska } & mean & 7.74 & 3.72 & 487 & 1129 \\
\hline & $\min$ & 6.99 & 0.70 & 70 & 145 \\
\hline & $\max$ & 8.40 & 7.30 & 1090 & 2141 \\
\hline & $S D$ & 0.35 & 1.42 & 213 & 484 \\
\hline \multirow[t]{4}{*}{ Crepina } & mean & 7.82 & 3.10 & 429 & 954 \\
\hline & $\min$ & 7.08 & 0.70 & 55 & 160 \\
\hline & $\max$ & 8.60 & 10.40 & 1700 & 3616 \\
\hline & $S D$ & 0.37 & 2.84 & 482 & 1057 \\
\hline \multirow[t]{4}{*}{ Neretva - Opuzen } & mean & 7.88 & 1.86 & 220 & 520 \\
\hline & $\min$ & 7.42 & 0.32 & 5.2 & 14.9 \\
\hline & $\max$ & 8.24 & 6.90 & 1035 & 2354 \\
\hline & $S D$ & 0.25 & 1.52 & 230 & 531 \\
\hline
\end{tabular}

Sea water intrusion in the Neretva River Valley appears as a direct consequence of the hydrological conditions. Therefore, the assessment of the water suitability for irrigation should be carried out during the growing season, when the demand for irrigation reaches the top. On the Fig. 2, the dynamics of the $E C_{i w}$ value as well as $\mathrm{Na}^{+}$and $\mathrm{Cl}^{-}$concentrations in water on the Neretva Opuzen monitoring station were shown. Electrical conductivity of water on this station reaches the highest value during the summer, and maximum determined value of $6.90 \mathrm{dS} \cdot \mathrm{m}^{-1}$ was recorded in July, 1999. In the same time, both sodium and chlorine concentrations were reaching the highest values, $1035 \mathrm{mg} \cdot 1^{-1}$ and $2345 \mathrm{mg} \cdot 1^{-1}$, respectively. After that period, salt concentration in water was declining, falling to the lowest level in December.

On Fig. 3, the dynamics of $E C_{i w}$ values as well as sodium and chlorine concentration in water on the Crepina monitoring station were shown. Maximum concentrations appeared during the summer. In 1999 and 2000, the highest values were approximately equal, reaching the maximum of $10 \mathrm{dS} \cdot \mathrm{m}^{-1}$. In 2001 , the salt con- 


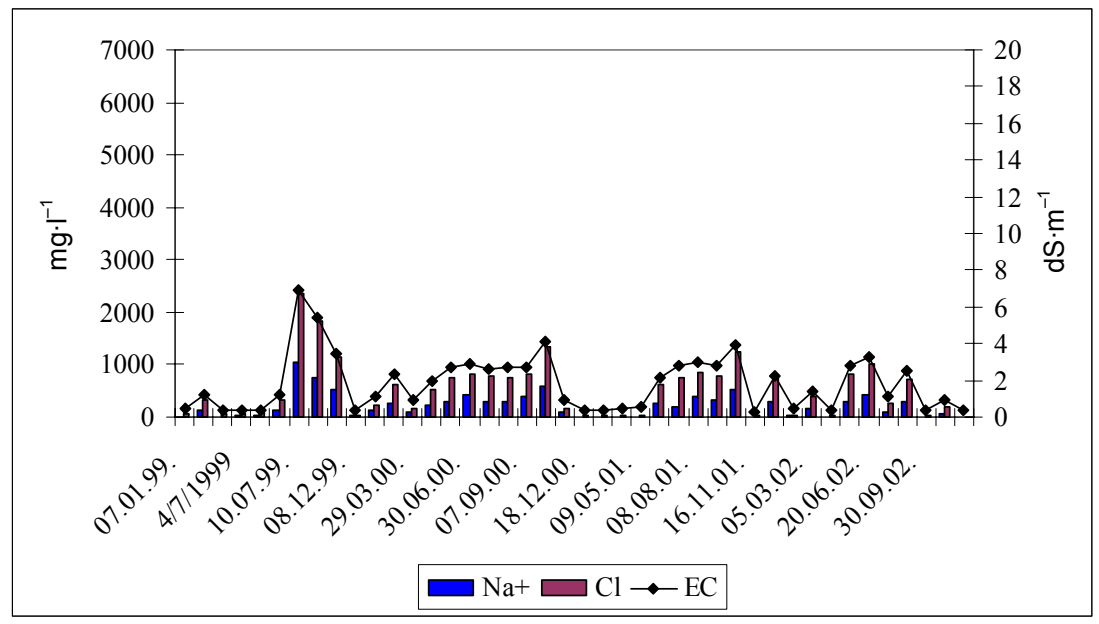

Fig. 2. Electrical conductivity, sodium and chlorine concentration in sampled surface water at the location Neretva near Opuzen (1999-2002)

centrations in general decreased, because the irrigation channel had been set in motion. By this channel, water overtaken upstream of Metković is brought to Crepina.

Channel Modric is the main drainage channel used also for irrigation during the growing season. The fluctuation of the $E C_{i w}$ values and concentrations of $\mathrm{Na}^{+}$ and $\mathrm{Cl}^{-}$were shown on Fig. 4. The values of electrical conductivity were not lower than $2 \mathrm{dS} \cdot \mathrm{m}^{-1}$. Moreover, unlike on the other locations maximum concentrations

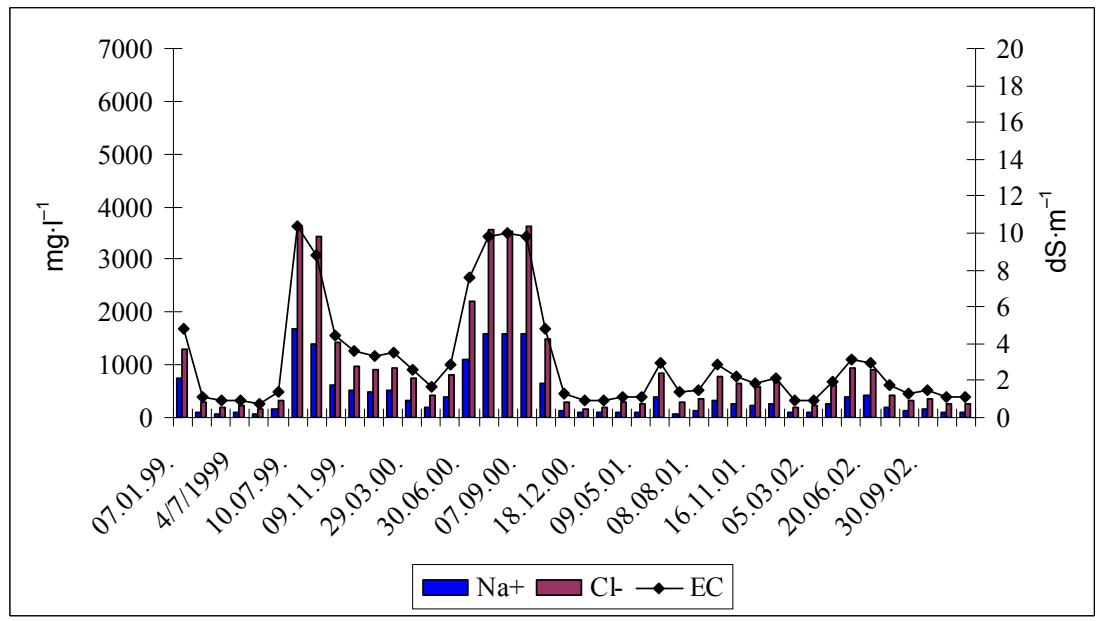

Fig. 3. Electrical conductivity, sodium and chlorine concentration in sampled surface water at the location Crepina (1999-2002) 


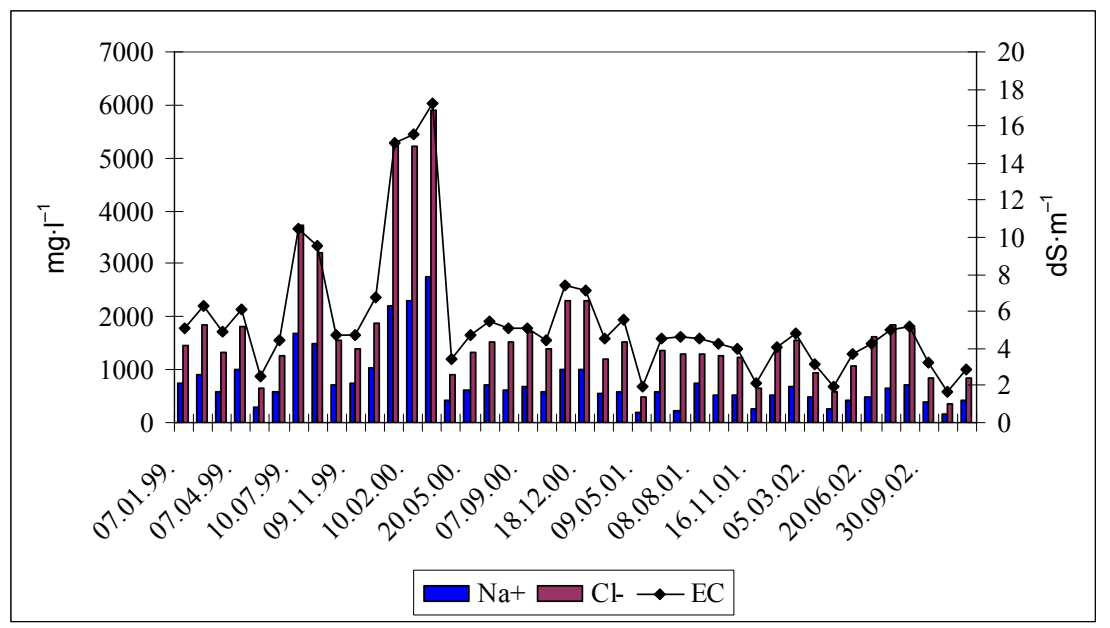

Fig. 4. Electrical conductivity, sodium and chlorine concentration in sampled surface water on the location Modric canal (1999-2002)

were appearing during the winter. Channel Modric also collects water that percolates through the agricultural land. Irrigation with saline water and capillary rising of the groundwater during the growing season result in the salt accumulation within the root zone. In the autumn and winter period salts have been leaching from soil after heavy rains and this process results in maintaining continuously high salt concentrations in the channel Modric water.

INFLUENCE OF WATER LEVEL AND THE AMOUNT OF PRECIPITATION ON DYNAMICS OF SURFACE WATER SALINITY

To assess the influence of average monthly precipitations on the value of $E C_{i w}$, the correlations between parameters were determined using data sets of measurements. Besides, the correlation between conductivity and water level was determined on the monitoring station Neretva near Opuzen. The average water level during the investigation period was $70.09 \mathrm{~cm}$ above the zero level. Maximum value was recorded in November, 2000. In 2001, the water levels were lower. The lowest level of $49.25 \mathrm{~cm}$ above the sea level was recorded in December, 2001. Low water level of the Neretva River in 2001 may be attributed to the low precipitation in the same year. The correlation between the conductivity and the water level on the Neretva Opuzen monitoring station is highly significant (Tab. 2). The correlation between the conductivity and the precipitation on the same location is weaker, but still statistically significant at $p<0.05$. 
Table 2. Relationship between surface water salinity (expressed as $E C_{i w}$ ) and the amount of precipitation on the monitoring locations, and relationship between precipitation and water level on location Neretva - Opuzen ( ${ }^{*}$ significantly different $p \leq 0.05, * *$ significantly different $p \leq 0.01$ )

\begin{tabular}{l|c|c}
\hline \multicolumn{1}{c|}{ Location } & Precipitation $* E C_{i w}$ & Water level *EC $C_{i w}$ \\
\hline Neretva near Opuzen & $-0.3766^{*}$ & $-0.4352^{* *}$ \\
Crepina & $-0.3376^{*}$ & \\
Vidrice & -0.0811 & \\
Modric canal & -0.0098 & \\
Jasenska & -0.2047 & \\
\hline
\end{tabular}

\section{DISCUSSION}

Soil cannot be considered as a simple mechanical filter, but as a complex system of the mineral origin acting as an exchanger of the different ions. Therefore, it is very important to know the quality of water which is applying by irrigation. The suitability of water for irrigation is determined by its physical, chemical and biological characteristics. Application of saline water requires adequate management (RHOADES, 1987).

Three ways of agricultural soil salinization were determined in the Neretva River valley: by capillary rising of the saline groundwater, irrigation with water of inadequate quality and bringing out of saline sediments to soil surface with ameliorative practices (ROMIC et al., 1998).

In this study, the fluctuation of the surface water salinity in the Neretva River delta was investigated. Water quality was measured on locations where irrigation water used in intensive agriculture is pumped. The results of monitoring show that the intensity of salinization is changing during the year. Changes of salinity are usually followed by the $\mathrm{pH}$ changes, as well as the concentrations of $\mathrm{Na}^{+}$and $\mathrm{Cl}^{-}$. From the end of October up to April, total salt concentrations are lower and water can be used with small or moderate limitation. During the drought period, when the requirements for water are the highest, water is usually brackish at the surface. The electrical conductivity value reached as much as $17.2 \mathrm{dS} \cdot \mathrm{m}^{-1}$ (channel Modric). Water of such quality should not be used for irrigation. Similarity between seasonal exchange of high and low conductivity values is evident on locations Jesenska, Crepina and Neretva - Opuzen, but on the channel Modric and Vidrice pumping station the feature of this changes looks different. Channel Modric and Vidrice pumping station are located near the main drainage channel very close to the sea. The values of conductivity and $\mathrm{Na}^{+}$and $\mathrm{Cl}^{-}$concentrations reach their maximum after the period of high precipitations that is in winter months (October-April). This phenomenon may be explained by the intensive use of highly salinized water during the summer months. Namely, salts from applied water precipitate 
in soil up to the depth of the root zone. Afterwards, the autumn rainfall leaches the salts from the surface soil to the channels.

The best situation was observed on the Neretva - Opuzen monitoring location. This is the natural course of the Neretva River influenced by the sea, but also by the large quantities of fresh water from the upper parts of the watershed and adjacent tributaries. Regular exchange of the low salinity in rainy period with the high salinity in drought period is evident on this particular location.

Nevertheless, constantly high concentrations of potassium and chlorine seem to be troublesome. Accumulation of sodium in soil may have pronouncedly negative effect on soil. Soil physical properties are especially affected. High sodium in the irrigation water causes often a severe soil permeability problem (QUIRK, 1986).

Statistical analysis resulted in highly significant correlation $(p \leq 0.01)$ between average monthly rainfall and the surface water salinity on Neretva - Opuzen monitoring station. Significant correlation was confirmed also between the rainfall and the water salinity on the monitoring location Crepina. No significant correlation was determined between electrical conductivity and average monthly rainfall on the other monitoring locations. In fact, Neretva - Opuzen and Crepina monitoring stations are natural river courses containing some quantities of dissolved salts. Dynamics of the surface water salinity on these locations are submitted under the direct influence of the ultimate hydrological regime of the Neretva River delta. Three remaining monitoring locations are placed inside the ameliorated area. These are hydrotechnical facilities and their functioning depends on the conditions of the ameliorated area and the scheduling of the water pumping. Therefore, the influence of the hydrological regime may be neglected on these locations. On the other hand, the collection of drainage water from the agricultural land has a substantial influence on the salt dynamics in surface waters.

Saline water irrigation and capillary rising of the salinized groundwater during the growing season result in salt accumulation in the root zone. Leaching of these salts takes place in autumn-winter period, usually after heavy rainfall. Long-term salinized soils may undergo to permanent modifications of their physical-chemical properties, which in turn may further aggravate damages to crop plants caused by saline irrigation. Hyper-osmotic stress, hypoxia, and nutritional imbalance often coexist in soils exposed to salinization, and they persist throughout the growth season (DE PASCALE et al., 2003).

\section{CONCLUSIONS}

Salt concentrations in surface waters of the Neretva River Valley are changing substantially during the year as a result of the hydrological regime. The results of the study show a spatial as well as a temporal variability of the water electrical conductivity and sodium and chlorine concentrations. The highest concentrations 
appear in summer months. High salt concentrations in water on locations Modric and Vidrice may have disastrous effect on the soil quality and also considerably impair crop yield. Moreover, a continuous applying of the saline water containing high sodium concentrations may permanently damage agricultural soils which are considered as one of the most valuable natural resources.

Monitoring of the water quality in addition to the adequate management may certainly prevent the damages on the agricultural land and crops.

Acknowledgements The project was supported by Ministry of agriculture, forestry and water management of the Republic of Croatia and by "Croatian waters".

\section{REFERENCES}

1. Ayers R.S., WeStCOT D.W., 1992. The use of saline waters for crop production. Irrigation and Drainage Paper, 48. Rome, FAO.

2. MAAS E.V., 1986. Salt tolerance of plants. Applied Agricult. Res., 1: 12-26.

3. De Pascale S., Ruggiero C., Barbieri G., Maggio A., 2003. Physiological responses of pepper to salinity and drought. J. Am. Soc. Horticult. Sci., 128, 1: 48-54.

4. RHOADES J.D., 1987. Principles of salinity control on food production in North America. In: Water and water policy in world food supplies. Texas A\&M, Univ. Press.: 141-151.

5. Romic D., Romic M., Borosic J., 1998. Influence of mulching on the leaching of nitrogen in bell pepper (Capsicum annuuum L.) growing. In: Innovative issues in irrigation and drainage. Proc. 1st Inter-regional conf. environment-water: Lisabon, Portugal, 16-18 Sept.: 28-34.

6. Statistica software version 7.1, 2006. StatSoft.

7. Standard methods for the examination of water and wastewater, 1995. 19th ed. Washington, D.C., APHA, AWWA and WEF.

\section{STRESZCZENIE}

\section{Problemy związane z jakością wód powierzchniowych wykorzystywanych do nawodnień $w$ delcie rzeki Neretwa (Chorwacja)}

Słowa kluczowe: intruzja wód morskich, nawadnianie, reżim wodny, zasolona wo$d a$, zasolenie gleb

Badania prowadzono w dolinie Neretwy, w południowej części chorwackiego obszaru krasowego, na którym działania hydrotechniczne w zlewni doprowadziły do napływu wody morskiej do warstw wodonośnych i w konsekwencji spowodowały zasolenie gleb w delcie rzeki. Region charakteryzuje się dużym potencjałem agroekologicznym i możliwością produkcji warzyw i owoców śródziemnomorskich. Ponieważ nałożenie się efektów zasolenia wód gruntowych i użycia tych wód do nawodnień może mieć fatalne skutki dla produktywności gleb, zainicjowa- 
no założenie sieci stałego monitoringu jakości wód. Celem tych badań było określenie dynamiki zasolenia wód powierzchniowych w czteroletnim okresie (1999-2002) na podstawie pomiarów w pięciu stanowiskach uznanych za potencjalne źródła wody do nawodnień (Kanał Modric, Neretwa koło Opuzen oraz stacje pomp Crepina, Jasenka i Vidrice). Próbki wód powierzchniowych pobierano co miesiąc i analizowano w nich wszystkie parametry niezbędne do oceny jakości wód do nawodnień. Stwierdzono znaczną zmienność mierzonych parametrów w czasie i w przestrzeni. Całkowita mineralizacja wód Neretwy koło Opuzen wynosiła od 0,4 do 7,7 dS $\cdot \mathrm{m}^{-1}$ a w Kanale Modric od 1,65 do 17,2 dS $\cdot \mathrm{m}^{-1}$. $\mathrm{Na}^{+} \mathrm{i} \mathrm{Cl}^{-}$były dominującymi jonami we wszystkich badanych stanowiskach. Stale duże stężenie $\mathrm{Na}^{+} \mathrm{w}$ próbkach wód powierzchniowych wymaga szczególnej troski. Stosowanie wody takiej jakości może powodować problemy związane z użyciem do nawodnień wód alkalicznych, co w przyszłości może prowadzić do całkowitej utraty żyznej gleby.

Reviewers:

Prof. Czestaw Rzekanowski

Prof. Andrzej Sapek 